\title{
CHARACTERISATION OF MOULDS FROM APPLE FRUIT IN HUNGARY
}

\author{
O. Csernusa*, J. Becznera, F. SeböK ${ }^{\mathrm{b}}$, M. Tóth ${ }^{\mathrm{c}}$ and Cs. DobolyI ${ }^{\mathrm{d}}$ \\ ${ }^{a}$ Department of Environmental and Applied Microbiology, Research Institute of Agro-Environmental Science, \\ National Agricultural Research and Innovation Centre, H-1022 Budapest, Herman Ottó út 15. Hungary \\ ${ }^{\mathrm{b}}$ Department of Environmental Protection and Environmental Safety, Szent István University, \\ H-2100 Gödöllő, Páter K. út 1. Hungary \\ ${ }^{\mathrm{c}}$ Faculty of Horticultural Science, Department of Pomology, Corvinus University of Budapest, \\ H-1118 Budapest, Villányi út 29-43. Hungary \\ ${ }^{\mathrm{d} U n i v e r s i t y ~ C e n t r e ~ o f ~ E x c e l l e n c e ~ i n ~ E n v i r o n m e n t a l ~ I n d u s t r y ~ B a s e d ~ o n ~ N a t u r a l ~ R e s o u r c e s, ~ S z e n t ~ I s t v a ́ n ~ U n i v e r s i t y, ~}$ \\ H-2100 Gödöllö, Páter K. út 1. Hungary
}

(Received: 6 June 2014; accepted: 22 July 2014)

\begin{abstract}
The surface microbial contamination is of great interest in case of fruit because of the threat of postharvest spoilage. Apple is a valuable product from growing, commercial, as well as from nutritional points of view. Apple diseases during the growing season can be satisfactorily controlled by different plant protection technologies, but postharvest decay of apples caused by the so called storage moulds cannot be completely avoided. Cold storage - alone, or in combination with other methods - is the main technology used to successfully prolong the shelf life of apples. The origin of the moulds causing the decay of apples during storage is not well understood. In this work the surface mycobiota of apple fruit grown in Soroksár, in the orchard of the Corvinus University of Budapest was investigated.

Keywords: apple, mould, Penicillium, postharvest
\end{abstract}

Fungi are overwhelmingly present in postharvest diseases of fruit. Moreover, mould contamination might result in mycotoxin production. Penicillium expansum, the so called blue mould, and Botrytis cinerea, the causative agent of grey mould disease, are the most common pathogens of apples (KADER, 2002). Penicillium spp. are responsible for the production of the mycotoxin patulin in apple fruit as well as the contamination of apple juices, as patulin survives the pasteurization process (BARKAI-GoLAN, 2008).

Other important postharvest disease of apple is the Mucor rot, the fungus being widely distributed in the apple growing regions. Alternaria rot may attack wounds and fleshy stems of the fruit. The fungus may contribute to "mouldy core". Cladosporium rot mould may colonise the bruised or wounded tissues during storage, particularly at the end of the shelf life of the fruit. The fungus may also be present in "mouldy cores" (KADER, 2002). Aspergillus spp. have also been isolated and known to cause infections in stored apples (КLICH, 2002).

Surface microbial contamination of apple cultivars from conventional and organic growing originating from different growing areas and years has already been investigated in Hungary (PinTÉr et al., 2010; PinTér, 2014), however, the contaminating mould species have not been identified.

The aim of this study was to characterise the moulds isolated from locally produced apples at the time of harvest and during cold storage. Identification processes of fungal

\footnotetext{
* To whom correspondence should be addressed. Phone/fax: +36-1-356-4673; e-mail: o.csernus@cfri.hu
} 
species in this work, as a first step, are based on mycelia (colour, size, and shape) and morphological characteristics (morphology of hyphae, conidia and conidiophores) (SAMSON \& FRISVAD, 2004).

\section{Materials and methods}

\subsection{Apples}

At two growing seasons (2010-2011), fruit of six cultivars ('Bőrkormos renet', 'Florina', 'Golden Delicious Reinders', 'Jonagold', 'Jonagold Rubinstar', and 'Produkta') were collected from the experimental orchard of the Department of Pomology (Corvinus University of Budapest) in Soroksár, Hungary. After harvest, apple fruit were stored in the cold store of the Department, at $4{ }^{\circ} \mathrm{C}$ for 6 months.

\subsection{Determination of mould counts}

Harvests of the apples were in September and the stored apples were investigated each month from November until the end of March. Mould counts were quantitatively determined according to MSZ ISO (1999), on malt agar. Five fruit of each cultivar were washed in Stomacher ${ }^{\circledR}$ bags of $90 \mathrm{ml}$ sterile physiological saline peptone water (peptone $1 \mathrm{~g}, \mathrm{NaCl} 9 \mathrm{~g}$ in $1000 \mathrm{ml}$ distilled water) manually shaking for 2 minutes in three parallels. The average surface of cultivars were calculated by measuring the apple diameters of 5 average sized apple fruit, and the microbiological results were calculated as colony forming unit per $\mathrm{cm}^{2}$ $\left(\mathrm{CFU} \mathrm{cm} \mathrm{cm}^{-2}\right)$.

\subsection{Isolation of moulds}

Well distinguished colonies were isolated and maintained on malt extract agar, MEA (PITT \& Hocking, 1997) at $4{ }^{\circ} \mathrm{C}$ at the Culture Collection of the Department of Environmental and Applied Microbiology of Research Institute of Agro-Environmental Science, Budapest, Hungary.

\subsection{Characterisation of isolates}

Petri dishes of MEA and CYA (Czapek yeast extract agar; PITT and HockING, 1997) and yeast soluble starch agar (4 g yeast extract; $15 \mathrm{~g}$ soluble starch; $1 \mathrm{~g} \mathrm{~K}_{2} \mathrm{HPO}_{4} ; 0.5 \mathrm{~g} \mathrm{MgSO}_{4} \times 7 \mathrm{H}_{2} \mathrm{O}$; $2 \%$ agar; $1000 \mathrm{ml}$ distilled water) were inoculated with the single cultures at three points. After 7 days of incubation at $25^{\circ} \mathrm{C}$, the diameters of macroscopic colonies were measured from the reverse side. Colony appearance was judged by a stereomicroscope. The micromorphological characteristics of isolates were examined by light microscope $(40 \times)$.

Isolates were identified according to the identification key of PITT and HockING (1997). Colony morphology on creatine sucrose agar (CREA) also was considered for the accurate identification of Penicillium isolates.

\subsection{Statistical analysis}

Shannon's diversity index (SHANNON \& WEAVER, 1949) was used for the measurement of taxonomical diversity calculated from the following equation: $H^{\prime}=-\Sigma\left[\mathrm{p}_{\mathrm{i}} \ln \left(\mathrm{p}_{\mathrm{i}}\right)\right]$, where $\mathrm{p}_{\mathrm{i}}$ represents the relative abundance of the $i$ th species isolated from the fruit of each cultivar. 


\section{Results and discussion}

\subsection{Quantitative mould contamination of apple fruit}

The levels of mould contamination of apple fruit of different cultivars in 2010 and 2011 are shown in Tables 1-2.

Table 1. Mould contamination ( $\mathrm{CFU} \mathrm{cm} \mathrm{cm}^{-2}$ ) of apple fruit of different cultivars during cold storage from the harvest of 2010

\begin{tabular}{lccccccc}
\hline Cultivars & $\begin{array}{c}28.09 .2010 \\
\text { Harvest }\end{array}$ & 10.11 .2010 & 07.12 .2010 & 10.01 .2011 & 07.02 .2011 & 09.03 .2011 & 29.03 .2011 \\
\hline $\begin{array}{l}\text { Börkormos } \\
\text { renet }\end{array}$ & 6 & 711 & 565 & 712 & 361 & 614 & 1461 \\
Florina & 5 & 558 & 346 & 558 & 1377 & 760 & 7027 \\
$\begin{array}{l}\text { Golden } \\
\text { Delicious }\end{array}$ & 4 & 2364 & 322 & 2602 & 1027 & 1230 & 22560 \\
Reinders & & & & & & & \\
Jonagold & 7 & 2895 & 325 & 2634 & deteriorated & & \\
$\begin{array}{l}\text { Jonagold } \\
\text { Rubinstar }\end{array}$ & 5 & 604 & 20 & 344 & 18 & 122 & 1202 \\
Produkta & 2 & 282 & 83 & 282 & 521 & 399 & deteriorated \\
\hline
\end{tabular}

Table 2. Mould contamination $\left(\mathrm{CFU} \mathrm{cm} \mathrm{cm}^{-2}\right)$ of apple fruit of different cultivars during cold storage from the harvest of 2011

\begin{tabular}{lccccc}
\hline Cultivars & $\begin{array}{c}19.09 .2011 \\
\text { Harvest }\end{array}$ & 08.11 .2011 & 04.01 .2012 & 27.01 .2012 & 10.02 .2012 \\
\hline Bőrkormos renet & 4 & 90 & 9 & 1156 & 840 \\
Florina & 3113 & 81 & 866 & 1664 & 189 \\
Golden Delicious Reinders & $<1$ & 299 & 444 & 3882 & 187 \\
Jonagold & 39 & 412 & 741 & 1985 & 1187 \\
Jonagold Rubinstar & 19 & 211 & 258 & 1523 & 1353 \\
Produkta & 24 & 124 & 26 & 312 & 439 \\
\hline
\end{tabular}

In 2010 the extremely rainy weeks prior to te apple harvest (database of the Hungarian Meteorological Service), resulted optimal conditions for the colonization and growth of moulds. In comparison, 2011 was a much hotter and drier year. The weather conditions 
(temperature and humidity) might influence the overall level of surface mould contamination of apple fruit to a certain degree during the vegetation season, and that might influence the level of surface contamination during storage. However, during storage, the storage conditions and the different characteristics of the fruit surface probably have more influence on the surface contamination, as it can be seen in the figures - in 2010 cultivars 'Golden Delicious Reinders' and 'Florina' seemed the most mould contaminated during the storage period. At the time of harvest (2010), the number of colonies detected was under $10 \mathrm{CFU} \mathrm{cm}^{-2}$. In 2011 , the time factor seemed more determining - there was an average slow increase in the level of surface contamination as a function of storage time, with two outstanding, independent results, probably due to sampling error. PINTÉR and co-workers (2010, 2014), investigating 33 apple cultivars (from organic and integrated production systems), found that the weather conditions are significant factors in the surface contamination of fruit, the more rainy and extreme weather conditions in 2010 reduced the surface contamination. In general, the organic production resulted in a (not significantly) higher mould surface contamination of apples. However, they did not investigate the influence of storage on the level of mould contamination.

\subsection{Characterisation of isolates}

Most of the isolates belonged to Penicillium subgenus Penicillium. Secondary spread of Penicillium occurred by nesting, usually a consequence of over-stored, senescent fruit. Blue mould spores survive for long periods on bins. For the accurate identification in subgenus Penicillium, a medium based on CREA was used in addition to MEA and CYA, and the colour of colony and the morphological characteristics of the mould were the basis of identification (Рiтt \& Hocking, 1997). Eight different Penicillium subgenus Penicillium species ( $P$. aethiopicum, $P$. aurantiogriseum, $P$. brevicompactum, $P$. chrysogenum, $P$. crustosum, $P$. expansum, $P$. nalgiovense, and $P$. solitum) were identified. One isolate belonged to Penicillium subgenus Aspergilloides. Decays developed from postharvest wounds were also caused by Aspergillus spp. Five diverse Aspergillus species (Asp. clavatus, Asp. parasiticus, Asp. tamarii, Asp. versicolor, and black aspergilli) were detected. Alternaria and Fusarium species cause postharvest decay. Alternaria sp. was identified on the basis of the production of large brown club shaped conidia, septated both laterally and longitudinally. Two Fusarium species (Fusarium graminearum, Fusarium sporotrichioides) heavily overgrowing the whole Petri dishes were also found. Mucor sp. spread across the whole Petri dish, but its growth was relatively low compared to Rhizopus sp. Other moulds (Acremonium sp., Cladosporium sp., Epicoccum nigrum, Trichoderma sp., Truncatella sp.) and sterile hyphae were also isolated from the surface of apples (Fig. 1).

According to the results, the relatively low storage temperature $\left(4{ }^{\circ} \mathrm{C}\right)$ did not inhibit completely the growth of Pencillium, Aspergillus, and Fusarium spp. and that of the other moulds. 


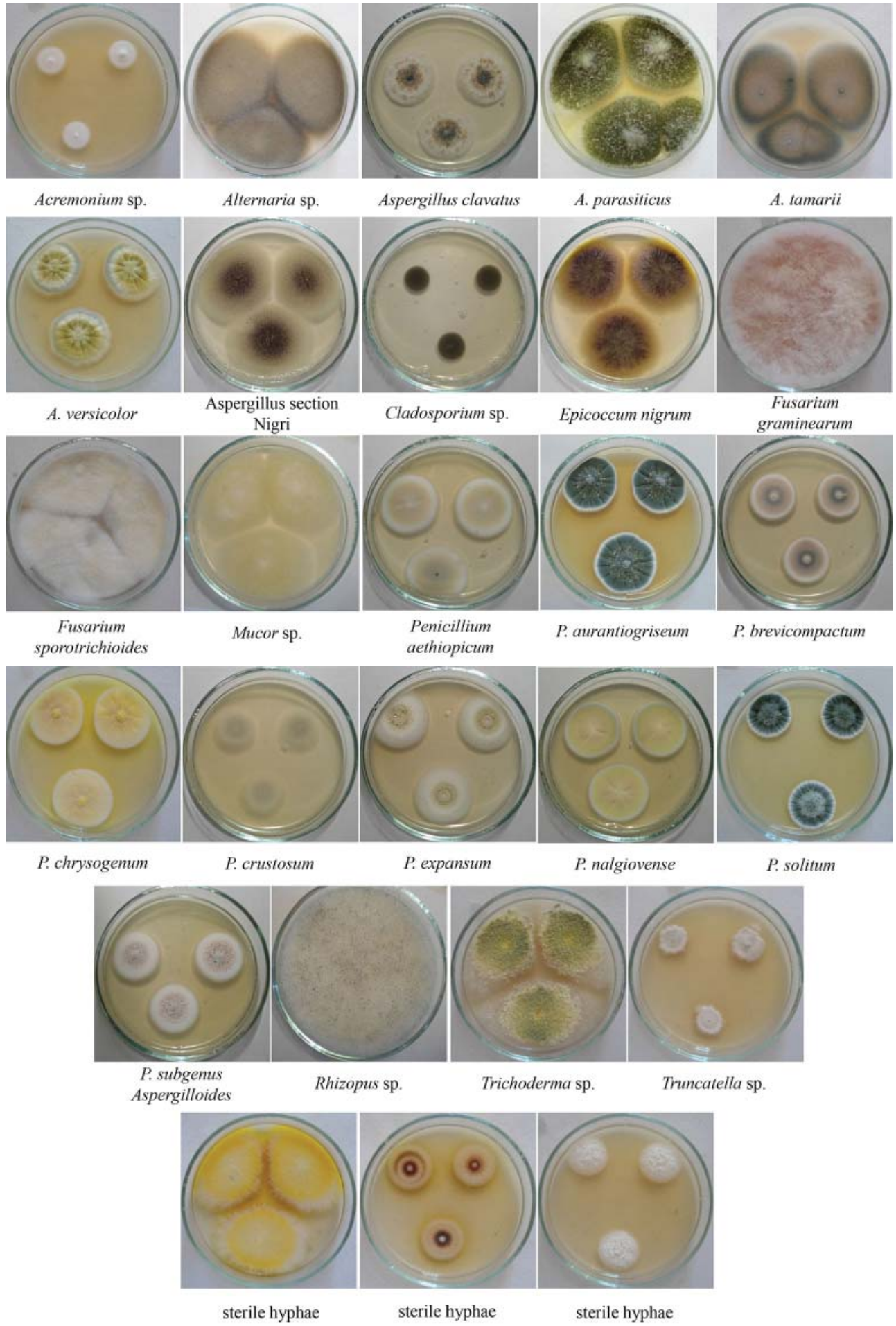

Fig. 1. Mould species isolated from apple surfaces on yeast soluble starch agar, incubated for 7 days at $25^{\circ} \mathrm{C}$ 


\subsection{Statistical analysis}

Diversity of moulds at both harvests was calculated (Tables 3-5). In 2010 the level of mould contamination was higher than in 2011, however the diversity did not grow with the number of moulds. The number of individuals was in inverse proportion to diversity.

Table 3. Diversity of moulds on the surface of apple fruit in 2010 by Shannon index

\begin{tabular}{lccc}
\hline Cultivars & Harvest & $1-3$ months & 4-8 months \\
\hline Börkormos renet & 0.57 & 0.92 & 0.37 \\
Florina & 0.00 & 1.15 & 0.14 \\
Golden Delicious Reinders & 0.52 & 1.23 & 0.20 \\
Jonagold & 0.00 & 0.21 & deteriorated \\
Jonagold Rubinstar & 0.45 & 0.83 & 0.43 \\
Produkta & 1.22 & 0.90 & 0.25 \\
\hline
\end{tabular}

Table 4. Diversity of moulds on the surface of apple fruit in 2011 by Shannon index

\begin{tabular}{lccc}
\hline Cultivars & Harvest & $1-3$ months & $4-8$ months \\
\hline Börkormos renet & 0.68 & 1.34 & 0.36 \\
Florina & 0.90 & 1.97 & 0.98 \\
Golden Delicious Reinders & 0.50 & 1.19 & 0.55 \\
Jonagold & 0.88 & 1.43 & 1.31 \\
Jonagold Rubinstar & 0.00 & 1.14 & 1.43 \\
Produkta & 0.66 & 1.49 & 1.67 \\
\hline
\end{tabular}

Table 5. Diversity of moulds on the surface of apple fruit of two harvests $(2010,2011)$ by Shannon index

\begin{tabular}{lll}
\hline Cultivars & 2010 & 2011 \\
\hline Bőrkormos renet & 0.89 & 1.48 \\
Florina & 0.55 & 1.75 \\
Golden Delicious Reinders & 0.89 & 0.81 \\
Jonagold & 0.35 & 2.06 \\
Jonagold Rubinstar & 1.51 & 1.63 \\
Produkta & 0.74 & 1.86 \\
\hline
\end{tabular}


With good agricultural practice the high level of mould contamination might be prevented. Presence of Penicillium expansum was detected during storage only, so the prevention could be the regular monitoring of apples for mould contamination during storage and timely processing.

\section{Conclusions}

Apples are contaminated with moulds in the orchard and later during storage. The occurrence and distribution of moulds on apple fruit is important partly because some of them may cause primary infections, diseases during vegetation (pathogenic species) and secondary infections/ rotting may occur during storage, and both events result in great losses. From food safety point of view, the main concern is the use of mouldy/rotten apples in the production of juices and ciders, because the processing conditions do not eliminate the toxin(s) (since the rigorous limits have been set for the mycotoxin levels in fruit juices and other products, the use of rotten fruit is mostly unintentional). Therefore the monitoring of apples during storage for the appearance/onset of toxin producing mould species, as well as the prediction of growth (and toxin production) of moulds would be of great importance (BARANYI et al., 2014; CsERnUS, 2014).

\section{References}

Baranyi, J., Csernus, O. \& Beczner, J. (2014): Error analysis in predictive modelling demonstrated on mould data. Int. J. Food Microbiol., 170, 79-82.

Barkai-Golan, R. (2008): Penicillium mycotoxins. -in: Barkai-Golan, R., Paster, N. (Eds) Mycotoxins in fruits and vegetables. Academic Press, New York, pp. 153-185.

CSERnus, O. (2014): Romlást okozó, potenciálisan toxinképzö penészgomba fajok növekedésének modellezése a hömérséklet és a vizaktivitás függvényében. (Predictive modelling of the growth of potentially toxigenic moulds as a function of temperature and water activity) PhD Thesis. Corvinus University of Budapest, 81 pages.

Kader, A.A. (2002): Postharvest technology of horticultural crops. ( ${ }^{\text {rd }}$ ed.) University of California, Agriculture and Natural Resources, pp. 197-205.

KLICH, M.A. (2002): Identification of common Aspergillus species, (1 $1^{\text {st }}$ ed.) Centraalbureau voor Schimmelcultures, Utrecht, The Netherlands, pp. 1-110.

MSZ ISO (1999): Mikrobiológia. Általános útmutató élesztök és penészek számlálásához. Telepszámlálási technika $25{ }^{\circ} \mathrm{C}$-on. (General guidance for enumeration of yeasts and moulds. Colony count technique at $25{ }^{\circ} \mathrm{C}$.) MSZ ISO 7954:1999

PINTÉR, Sz. (2014): Ökológiai és integrált gazdálkodással termesztett csonthéjas és almatermésü gyümölcsök mikrobiológiai és kémiai analizise. (Microbiological and chemical analysis of stone and apple fruits originating from ecological and integrated production systems) PhD Thesis. Corvinus University of Budapest, 160 pages.

Pintér, Sz., Beczner, J., Szabó, Z. \& Nyéki, L. (2010): Epiphytic microbiota of apple in integral and organic growing. Int. J. Hortic. Sci., 16(3), 85-89.

PitT, J.I. \& Hocking, A.D. (1997): Fungi and food spoilage. ( $2^{\text {nd }}$ ed.) Blackie Academic \& Professional, London, pp. $203-417$.

SAmson, R.A. \& Frisvad, J.C. (2004): Penicillium subgenus Penicillium: new taxonomic schemes, mycotoxins and other extrolites. Studies in Mycology No. 49, 251 pages.

Shannon, C.E. \& Weaver, W. (1949): The mathematical theory of communication. University of Illinois Press, Urbana, IL, 117 pages. 